\title{
RESPONSABILIDADE SOCIAL EM INSTITUIÇÕES FINANCEIRAS E INVESTIMENTOS RESPONSÁVEIS EM TEMPOS DE PANDEMIA
}

SOCIAL RESPONSIBILITY IN FINANCIAL INSTITUTIONS AND RESPONSIBLE INVESTMENTS IN PANDEMIC TIMES

\section{Maria da Graça de Oliveira Carlos}

Doutora em Administração de Empresas pela Universidade de Fortaleza (Fortaleza/Brasil).

Professora no Centro Universitário Estácio (Fortaleza/Brasil).

E-mail:mgcarlo@globo.com

\section{Dafne Oliveira Carlos de Morais}

Doutora em Administração de Empresas pela Fundação Getulio Vargas, Escola de Administração de Empresas de São Paulo (São Paulo/Brasil). Professora no Centro Universitário da Fundação Educacional

Inaciana Padre Sabóia de Medeiros (São Paulo/Brasil).

E-mail: dafne.morais@fei.edu.br 


\section{RESUMO}

O setor financeiro tem sido percebido como importante instrumento de redução da pobreza global. Essa pesquisa analisa as iniciativas institucionais que refletem a responsabilidade social de entidades financeiras do mundo, direcionadas aos seus clientes e demais stakeholders, como suporte prestado e investimentos sociais no âmbito de sua atuação durante a pandemia. A pesquisa é definida como quantitativa, exploratória e descritiva, com coleta transversal de dados secundários. Após os testes, foi possivel confirmar as hipóteses de que existem diferenças estatisticamente significativas entre as iniciativas das instituições financeiras que aderem ao UNEPFI, bem como daquelas que atuaram na Covid-19 a depender do fato de serem ou não signatárias dos Princípios de Responsabilidade Bancária (PRB), contudo, essas iniciativas não são significativamente diferentes em relação a sua região de origem. O estudo contribui ao delinear uma visão global e estruturada do tema, apresentando o perfil das empresas do setor que aderem às diretrizes de finanças sustentáveis no mundo e descrevendo os investimentos realizados pelos signatários dos PRB como apoio à sociedade durante a pandemia.

Palavras-chave: Responsabilidade Social. Instituições Financeiras. Fatores ESG.

\section{ABSTRACT}

The financial sector has been perceived as an important instrument of global poverty reduction. The research aims to analyze the institutional initiatives that reflect the social responsibility of financial entities, in the different regions of the world, directed to their clients and other stakeholders, as support and social investments within the scope of their performance during the pandemic. Quantitative, exploratory and descriptive research, with transversal collection of secondary data. After the tests, it was possible to confirm the hypotheses that there are statistically significant differences between the initiatives of the financial institutions that adhere to UNEPFI, as well as those that worked at Covid-19, depending on whether or not they are signatories to the Principles of Banking Responsibility (PRB), however, these initiatives are not significantly different in relation to their region of origin. The study also addresses the PBR and contributes by providing a global and structured view of the theme, presenting the profile of companies in the sector that adhere to sustainable finance guidelines in the world and describing the investments made by the signatories of the PRB as support to society during the pandemic.

Keywords: Social responsability. Financial Institutions. ESG factors. 


\section{INTRODUÇÃO}

O contexto contemporâneo, que tem como pano de fundo a pandemia da Covid-19, tem se mostrado um desafio complexo, evidenciado por milhões de indivíduos infectados e milhares de óbitos, dramas pessoais e familiares. A quantidade de vítimas da primeira onda alcançou o patamar de 50 milhões infectados e mais de 1,3 milhão de óbitos (ALVES, 2019; WHO, 2019). 0 ataque do vírus desencadeou situações alarmantes, marcadas pelo desconhecimento da patologia, centralização de insumos e produção de instrumentos em poucos fornecedores, sendo agravadas pela inexistência de tratamento e politização do tema. O surto da doença trouxe à tona situações cruciais de uma crise sanitária, agravada por crises econômicas e políticas, que exigem respostas globais. A pandemia é um apelo sem precedentes, que pede suporte institucional, seja no repasse de recursos ou na assistência pelos governos e demais entidades.

A quarentena foi uma estratégia de redução de danos que deu uma trégua às equipes e sistemas de saúde, mas que ocasionou o fechamento de milhões de negócios e de postos de trabalho em diversos setores. Em meio ao caos humanitário, o mundo assistiu à reação de mercados e bolsas em looping, devido à parada das instituições de comércio, indústria e grande parte dos serviços com a restrição de mobilidade, fechamento de fronteiras e aeroportos. Essa conjuntura mostrou a retração econômica e a necessidade de atender às populações vulneráveis com recursos, seja pela criação de uma renda emergencial destinada ao cidadão ou pelo financiamento subsidiado aos pequenos empreendimentos, a infraestrutura de suporte e/ou fomento a grupos e setores específicos.

O Fundo Monetário Internacional (FMI) projetou a contração do crescimento global para 2020 de 4,9\% e, para 2021, o crescimento dependerá do surto de novas infecções (REUTERS, 2020). Por sua vez, o Fórum Econômico Mundial menciona que a redução da atividade econômica durante a pandemia exigiu a injeção de trilhões de dólares para suportar a situação até uma próxima recuperação (O GLOBO, 2020).

Assim, emerge a atuação das instituições financeiras, que passaram a intermediar a alocação de recursos dos governos, destinadas às populações vulneráveis com destaque do papel das entidades bancárias. Para cumprir sua finalidade, o setor pode criar empoderamento financeiro, empregos e crescimento econômico, se tratar clientes, acionistas e sociedade com respeito, unindo lucro e propósito (BOTIN, 2018).

O setor financeiro tem sido percebido como importante instrumento de redução da pobreza global, em parte pelo impacto social das operações bancárias, em parte pela materialidade dessas operações (WCED, 2018). Um número crescente de especialistas em investimentos acredita que fatores ambientais, sociais e de governança corporativa (i.e., do inglês Environmental, Social and corporate Governance, sigla 
conhecida como ESG) podem influenciar o desempenho das carteiras de investimento, um dever fiduciário dos investidores (SULLIVAN et al., 2015).

Sem data marcada para acabar, a pandemia do Corona vírus mostrou forte capacidade de prejudicar a atividade econômica em todo o mundo e não parece haver solução no horizonte imediato. De todo modo, os mercados de ações norte-americanos e globais se recuperam aos poucos com a expectativa dos resultados das vacinas (LEVEN, 2019). Tendo em vista esse contexto, o presente estudo questiona: Quais iniciativas institucionais refletem a responsabilidade social de entidades financeiras durante a pandemia?

A pesquisa tem como objetivo analisar as iniciativas institucionais que refletem a responsabilidade social de entidades financeiras, nas diversas regiões do mundo, direcionadas aos seus clientes e demais stakeholders, como suporte prestado e investimentos sociais em sua atuação na pandemia. Para tanto, o estudo: i) descreve o perfil das entidades financeiras atuantes, ii) descreve as iniciativas realizadas pelas entidades e os principais beneficiados. Ainda, iii) compara as iniciativas quanto à localidade e aos princípios de responsabilidade bancária e, iv) testa se as iniciativas refletem as diretrizes de sustentabilidade declaradas.

Alguns estudiosos analisaram instituições financeiras quanto às suas práticas de sustentabilidade (ALMEIDA; JUNIOR; COSTA, 2017). Contudo, a investigação considerou apenas quatro instituições brasileiras, em um contexto pré-pandemia, sob análise qualitativa e descritiva. O presente estudo considera instituições em âmbito global, analisadas de modo qualitativo e quantitativo. A pesquisa também adota o conceito de responsabilidade social, fundamentos de investimentos sociais e finanças sustentáveis em entidades financeiras que aderem às pautas da ONU a partir das iniciativas da UNEPFI, braço da ONU para assuntos de finanças e meio ambiente.

O estudo aborda os Princípios de Responsabilidade Bancária (PRB) e contribui ao prover uma visão global e estruturada do tema, apresentando o perfil das empresas do setor que aderem às diretrizes de finanças sustentáveis no mundo e descrevendo os investimentos realizados pelos signatários dos PRB como apoio à sociedade durante a Covid-19. Em um contexto dinâmico, o estudo está na vanguarda ao prover visão global e estruturada no tema.

$\mathrm{O}$ artigo apresenta cinco seções além da introdutória. As seções 2 e 3 apresentam temas centrais do referencial teórico: Responsabilidade Social e Investimentos Sociais e Finanças Sustentáveis e Investimentos Responsáveis. A seção seguinte traz as explicações metodológicas, seguida pela descrição e análise dos conteúdos e, por fim, das conclusões. 


\section{RESPONSABILIDADE SOCIAL E INVESTIMENTOS SOCIAIS}

As atividades econômicas emergem da troca e do empréstimo de dinheiro, mais tarde expandidas por transações de depósito. As transações foram reguladas por normas éticas durante séculos, especialmente no que se referia aos empréstimos (FEKETE; TATAY, 2013)

Durante o século XX, a abordagem do desempenho econômico-financeiro prevaleceu no ambiente de negócios e investimentos, cuja pauta esteve centrada nos acionistas, também conhecidos como shareholders. Nesse contexto, os poderes concedidos à empresa e à gestão deveriam convergir para 0 benefício dos shareholders (BERLE, 1931), sendo função do negócio produzir ganhos de alta magnitude com retorno sustentável (LEVITT, 1958). Sob os auspícios de Friedman (1970), as organizações foram declaradas construções legais, amorais, para obter/maximizar lucro. A responsabilidade social foi considerada como prática ilícita, com impactos negativos na rentabilidade da firma.

Com os anos, contudo, emergiram pautas propondo incluir valores e preocupações sociais na tomada de decisão (BOWEN, 1957) e evidências de que o desempenho social poderia ser influenciado pelos mercados de capitais, que respondem a pressões de investidores e clientes e percebem novas metas para o dinheiro (MOSKOWITZ, 1972).

As políticas socialmente responsáveis e o respeito por valores morais e sociais têm sido mencionados como indicadores teóricos do desempenho social da empresa, no qual emergem importantes dimensões da atividade empresarial: i) os princípios, como valores que balizam as políticas de responsabilidade social; ii) os processos, como mecanismos utilizados para atuar socialmente; e iii) as políticas sociais (WARTICK; COCHRAN, 1985).

As iniciativas para surgimento dos investimentos sustentáveis fortaleceram-se nos anos 1990. Ulrich (2016) sugere uma breve retrospectiva a partir das cobranças da sociedade junto a investidores, o que desencadeou ações e respostas institucionais ao longo do tempo. Alguns marcos temporais estão expostos no Quadro 1. 


\begin{tabular}{|c|c|}
\hline Data & Descrição \\
\hline $\begin{array}{l}\text { Final } \\
\text { déc } 60\end{array}$ & $\begin{array}{l}\text { A oposição à Guerra do Vietnã leva os estudantes a pedir que as carteiras de investimento de suas } \\
\text { universidades deixem de investir em empreiteiras militares. }\end{array}$ \\
\hline 1989 & $\begin{array}{l}\text { O petroleiro Exxon Valdez encalha no Alasca, derramando de } 11 \text { a } 38 \text { milhões de galões de petróleo e } \\
\text { criando desastre marítimo, evento marcante para o movimento ambiental global }\end{array}$ \\
\hline 1999 & $\begin{array}{l}\text { Lançamento do Dow Jones Sustainability Index, primeiro índice global de sustentabilidade criado por } \\
\text { SustainabilityAsset Management (depois Robeco SAM). Dow Jones Indexes, líder global do mercado de índices } \\
\text { de ações, se estabelece como pioneiro da ideia da sustentabilidade. }\end{array}$ \\
\hline 2006 & $\begin{array}{l}\text { ONU lança os Princípios para Investimento Responsável (PRI). Iniciativa surge de rede internacional de } \\
\text { investidores que criam } 6 \text { princípios para ajudar participantes do mercado e signatários a entender efeitos da } \\
\text { sustentabilidade e incorporá-los em decisões de investimento e práticas de propriedade. }\end{array}$ \\
\hline 2008 & $\begin{array}{l}\text { O mercado acionário entra em crise e os investidores mudam de foco para as questões ESG, se } \\
\text { concentrando em resultados no longo prazo em lugar de ganhos no curto prazo. }\end{array}$ \\
\hline 2009 & $\begin{array}{l}\text { A S\&P Indices lança o S\&P Carbon Efficient Select Index com Trucost, o primeiro índice a considerar a } \\
\text { mudança do clima e que combina os benefícios da descarbonização das carteiras com um perfil de risco e } \\
\text { retorno similar ao de benchmarks padrão }\end{array}$ \\
\hline 2012 & $\begin{array}{l}\text { Fusão de S\&P Indices e Dow Jones Indexes, unindo séries sólidas de índices de sustentabilidade e } \\
\text { estabelecem a base para o crescimento de soluções de sustentabilidade baseadas em índices }\end{array}$ \\
\hline 2015 & $\begin{array}{l}\text { Em Le Bourget, França, } 195 \text { países alcançam acordo histórico que, pela primeira vez, compromete quase } \\
\text { todas as nações a reduzir emissões de GEE para ajudar a combater a mudança do clima }\end{array}$ \\
\hline
\end{tabular}

\section{Fonte: S\&P Dow Jones Indices e Ulrich (2016) (adaptado pelos autores)}

Estudos no tema de investimentos sociais no Brasil mostram diversidade de achados em suas investigações. Alguns autores encontram relações positivas entre investimento social e práticas sustentáveis. Já outros, não encontram qualquer relação ou até mesmo relações negativas. Evidenciando alguns desses achados, temos Milani Filho (2008), que investigou o investimento social privado declarado por 52 empresas listadas na Bolsa. 0 autor verificou baixa divulgação em relatórios, especialmente pelas firmas que negociam armas, bebidas alcóolicas e cigarros e maior disclosure em firmas indexadas na carteira do Índice de Sustentabilidade Empresarial (ISE). Por sua vez, Machado et al. (2008) estudaram a contribuição dos investimentos sociais para resultados financeiros a partir do balanço social de 61 empresas brasileiras, verificando impacto positivo dos investimentos sociais internos. Pereira e Gil (2009) verificaram percepções de 25 dirigentes de organizações sem fins lucrativos, no ABC Paulista, acerca do investimento social e viram que tais empresas atuaram com responsabilidade social, para divulgar sua imagem e marca dos seus produtos e serviços. 
Campos e Lemme (2009) examinaram o desempenho no mercado de capitais de índices internacionais e fundos de ações nacionais orientados para o conceito de Investimento Social Responsável (ISR), buscando evidências de possíveis impactos sobre o desempenho financeiro. Os resultados indicaram inexistência de diferenças estatisticamente significativas de risco e retorno entre os índices e carteiras ISR examinados e seus benchmarks.

Santos et al. (2013) analisaram se as empresas listadas no Índice de Carbono Eficiente (ICO2) possuem melhor desempenho médio no preço e retorno de suas ações em detrimento das empresas não listadas. Os autores analisaram seis empresas e não encontraram evidências que a listagem no ICO2 garante maior valorização de ações. Maciel e Montezano (2016) compararam as carteiras de ações de Fundos Socialmente Responsáveis (FSRs) e de Fundos Convencionais de investimento em ações (FCs) e encontraram alguns modelos que mostram que os FSRs, na média, têm retornos anormais abaixo dos retornos anormais dos FCs, destruindo valor para investidores e que os FSRs são mais defensivos e menos diversificados do que os FCs.

Gentil, Ferreira e Rodrigues (2019) analisaram o retorno de Investimentos Sociais Privados (ISP) de empresas integrantes da carteira ISE e revelam o alinhamento do tema à estratégia da empresa. Por outro lado, Diniz et al. (2020) investigaram três casos de empresas listadas no guia exame de sustentabilidade em busca de aspectos inadequados ao conceito de sustentabilidade. Os autores apontam que os feitos tidos como sustentáveis são desenvolvidos em paralelo a outras atividades que podem ser caracterizadas como injustas e/ou prejudiciais ao meio ambiente e que é preciso questionar ações empresariais por trás de práticas tidas como sustentáveis.

\section{INVESTIMENTOS RESPONSÁVEIS E FINANÇAS SOCIAIS: CONCEITOS E MODELOS}

O Investimento Social Corporativo (ISC) é compreendido como uma alocação de recursos financeiros, humanos, técnicos e gerenciais realizada pelas firmas de forma voluntária e planejada, com foco no interesse público (DUPRAT, 2005). Para o autor, essa modalidade de investimento apresenta quatro características: a) Catalisadora: consegue efetivar mudanças sociais, ambientais ou culturais; b) Alavancadora: tem poder de atrair novas parcerias estratégicas, coadunando para composição de redes de cooperação interempresarial e/ou intersetorial; c) Inovadora: as tecnologias são aperfeiçoadas por novos métodos advindos do contexto sócio/econômico/ambiental de sua implementação ou dos valores e competências da organização empresarial e parceiras; e d) Provocadora de mudanças: políticas sociais (projetos desenvolvidos), por contribuir para efetivação de políticas públicas, levam gestores/sociedade a composição de novas conexões e análises, potencializando mudanças em sua tessitura legal. 
O Investimento Social, também apontado como Investimento Social Privado (ISP), caracterizase pela transferência voluntária de recursos de empresas privadas para projetos sociais, ambientais e culturais de interesse público (MILANO FILHO, 2008). O ISP é entendido como parte de um movimento de deslocamento do capitalismo, ou seja, de uma resposta empresarial às necessidades de redefinir o espírito do capitalismo (PERRET; JUNQUEIRA, 2011). O ISP refere-se ao uso planejado, monitorado e voluntário de recursos privados, de pessoas físicas ou jurídicas, em projetos de interesse público (GIFE, 2015).

Por sua vez, as Finanças Sociais referem-se ao direcionamento a negócios de impacto ou a ações com mecanismos financeiros para gerar impacto social com sustentabilidade financeira. $O$ termo surge do entendimento que a complexidade dos problemas sociais requer soluções inovadoras e empreendedoras, atraindo capitais privados às formas tradicionais de financiamento do setor social, financiamento público, filantropia (FTFS, 2017). Bancos e agências de desenvolvimento podem contribuir no alinhamento e disseminação de finanças sociais e seus mecanismos, com relação aos tipos de investimento, dos quais salienta-se o investimento de impacto (FTFS, 2014).

Os investimentos de impacto consistem no direcionamento de capital público ou privado - como empréstimo, contratação, investimento ou doação - para instrumentos financeiros e negócios de impacto com o compromisso de gerar impacto social ou ambiental com rentabilidade financeira. Diferencia-se da filantropia e das finanças tradicionais por combinar as seguintes características: compromisso do capital com o impacto social, garantindo ainda um retorno financeiro, no caso dos investidores; e o monitoramento e mensuração do impacto, de modo que as ações implementadas precisam comprovar periodicamente seu impacto nos indicadores sociais e seu resultado financeiro (FTFS, 2017).

No Brasil, a Força Tarefa de Finanças Sociais (FTFS) foi criada com a finalidade de captar fomento para financiar soluções inovadoras que respondam a problemas sociais e tem se debruçado sobre a produção, análise e debates no campo das finanças sociais, contemplando investimentos que geram, a um só tempo, retornos sociais e ambientais e rentabilidade financeira (PIAZZON, 2017). A FTFS é uma entidade vinculada ao Global Social Impact Investment Steering Group.

O Papa Francisco declarou em conferência realizada em 2014 sua visão acerca do investimento de impacto, ressaltando que pretendem produzir um impacto social positivo para as populações locais, como a criação de postos de trabalho, o acesso à energia, à instrução e ao crescimento da produtividade agrícola. Os lucros financeiros para os investidores são inferiores em relação a outras tipologias de investimento. O Santo Papa descreve a característica do impact investor, cujo perfil deve configurar-se como um investidor consciente da existência de situaç̃oes de iniquidade graves, de desigualdades sociais profundas e das penosas condições de desvantagem nas quais se encontram populações inteiras. Ele se dirige a instituições financeiras que utilizam os recursos para promover o desenvolvimento económico e 


\section{Gestãoe \\ Desenvolvimento}

e-ISSN: 2446-6875

p-ISSN: $1807-5436$

social das populações pobres, com fundos de investimentos destinados a satisfazer as suas necessidades básicas ligadas à agricultura, ao acesso à água, à possibilidade de dispor de alojamentos dignos a preços acessiveis, bem como de serviços primários para a saúde e a educação. O Papa Francisco encaminha um conselho aos povos e pondera que os governos e nações através do mundo devem se comprometer a desenvolver um modelo ou estrutura internacional capaz de promover um mercado de investimentos de alto impacto e, assim, combater uma economia que exclui e descarta.

Ullrich (2016) menciona o investimento sustentável como um dos segmentos de mais rápido crescimento na indústria de gestão de ativos, assim como um dos mais complexos, e pontua que investir de forma sustentável significa integrar questões "extra-financeiras" nas decisões de investimento. Para tanto, há necessidade de estabelecer as diversas formas que tais investimentos não-financeiros podem se manifestar. Nessa direção, Ulrich (2016) ressalta os investimentos baseados em fatores ESG, que têm abrangência maior e envolvem a cidadania corporativa, o desenvolvimento de capital humano, o impacto ambiental da empresa e suas emissões de carbono, de grande relevância, pois de per si representa um indicador que monitora a mudança do clima, representando a modalidade de Investimento Verde.

Os fatores ESG representam os critérios de responsabilidade cujas dimensões ambientais, sociais e de governança corporativa definem critérios de ação e decisão por parte de uma entidade ou indivíduo, conforme Figura 1. No caso de um investidor, essas dimensões caracterizam um investimento sustentável e determinam as dimensões de ambiente.

Figura 1 - Fatores ESG

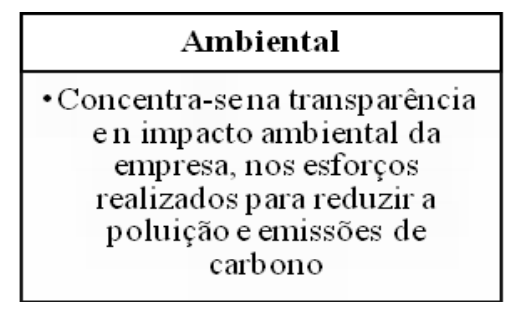

carbono

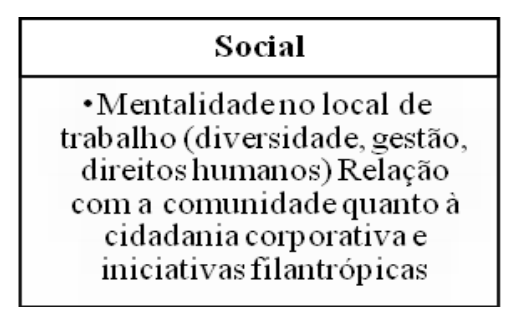

Fonte: Ulrich (2016)

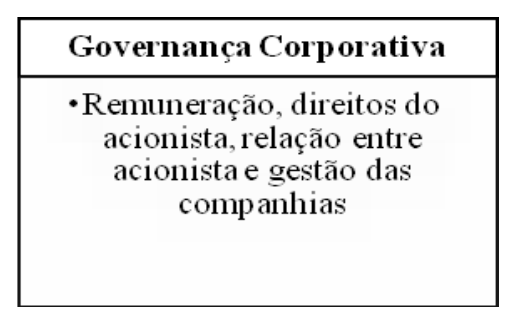

A iniciativa Princípios para Investimento Responsável (PRI) representa um dos projetos de grande relevância lançado pelo Pacto Global das Nações Unidas (UNGC) e pela Iniciativa Financeira do Programa das Nações Unidas para o Meio Ambiente (UNEPFI) para promover a consideração de fatores ESG e emissões por investidores institucionais (GOND; PIANI, 2012). Lançado em 2006, os PRI compõem uma iniciativa voluntária para estimular investidores do mundo a incorporar fatores ESG em análises de investimento (ALMEIDA; JUNIOR; COSTA, 2017). 


\section{Gestãoe \\ Desenvolvimento}

e-ISSN: 2446-6875

p-ISSN: $1807-5436$

A iniciativa do PRI contemplou a definição do papel do setor empresarial e das instituições financeiras no estabelecimento e implementação de ações concretas e pragmáticas dos negócios e processos, visando a adequação ao modelo de economia verde. Foi resultante de uma das pautas da Conferência das Nações Unidas sobre o Desenvolvimento Sustentável, também conhecida como Rio +20, em junho de 2012, no Brasil-Rio de Janeiro, onde se reuniram os representantes de 193 Estados Membros da ONU em diversos setores (YOSHIDA et al., 2017).

Assim, foi criado o PRI em 2012, com apoio do UNEP FI aos princípios do setor financeiro global visando catalisar a integração da sustentabilidade nas práticas do mercado financeiro com a missão de promover finanças sustentáveis. O investimento responsável não exige o investimento em uma estratégia ou produto de investimento específicos. Contudo, envolve a inclusão de informações ESG nas práticas de tomada de decisão e gestão de investimentos, para garantir que todos os fatores relevantes sejam levados em consideração durante a avaliação de risco e retorno. As diretrizes do PRI estão no Quadro 2, a seguir.

Quadro 2 - Princípios de Investimentos Responsáveis

\begin{tabular}{|c|l|}
\hline Princípios & \multicolumn{1}{c|}{ Iniciativas } \\
\hline Princípio 1 & Incorporaremos as questões ESG nos processos de análise de investimento e tomada de decisão. \\
\hline Princípio 2 & Incentivar pesquisas acadêmicas e outras sobre esse tema. \\
\hline Princípio 3 & $\begin{array}{l}\text { Participar do desenvolvimento de políticas, regulamentos e estabelecimento de padrões (como } \\
\text { promover e proteger os direitos dos acionistas). Resoluções dos acionistas de arquivos consistentes com } \\
\text { considerações ESG de longo prazo. }\end{array}$ \\
\hline Princípio 4 & Promoveremos a aceitação e implementação dos Princípios no setor de investimentos. \\
\hline Princípio 5 & Trabalharemos juntos para melhorar nossa eficácia na implementação dos Princípios. \\
\hline Princípio 6 & Cada um de nós relatará nossas atividades e progredirá na implementação dos Princípios. \\
\hline
\end{tabular}

\section{Fonte: PRI/UNEPFI (adaptado pelos autores)}

Embora os bancos tenham menor impacto direto sobre o meio ambiente, sua responsabilidade socioambiental indireta pode ser cobrada se concederem crédito a empresas que poluem, produzem produtos que violam direitos humanos (IDOWU FILHO, 2009).

A Iniciativa Financeira do Programa Ambiental das Nações Unidas (UNEPFI) é uma parceria da ONU com o setor financeiro global. Criada em 1992 após a cúpula da Terra - Eco 92 trabalha com bancos membros para aumentar os empréstimos que apoiam atividades econômicas social e ambientalmente sustentáveis e visa mobilizar financiamento do setor privado para o desenvolvimento sustentável.

A UNEPFI (2020) trabalha com mais de 300 membros, entre bancos, seguradoras, investidores que aderem às suas pautas, além de possuírem mais de 100 instituições de apoio de outros setores, para 
ajudar a criar um setor financeiro que atenda às pessoas e ao planeta, e produza impactos positivos. Seu objetivo é mobilizar o financiamento do setor privado para o desenvolvimento sustentável e entender seus desafios ambientais, sociais e de governança.

O setor bancário desempenha um papel crítico na promoção do desenvolvimento sustentável por sua capacidade de liderar o caminho rumo a uma economia mais sustentável, emprestando recursos para as atividades econômicas que geram o melhor retorno, do ponto de vista da sociedade, e fornecendo orientação a clientes e partes interessadas quanto ao gerenciamento de desafios e oportunidades sociais e ambientais (UNEPFI, 2020).

As instituições do setor de bancos vêm se mobilizando desde 2017, por ocasião da ação da Força Tarefa direcionada a Divulgação de Ações sobre Mudanças Climáticas (Task Force on Climate-related Financial Disclosures) - TCFD, comandada pelo Financial Stability Board (FSB), que recomendou aos países do G-20 o alinhamento do disclosure das práticas de investimento e dos fluxos financeiros com os objetivos climáticos de longo prazo.

A iniciativa da TCFD e as diretrizes da responsabilidade bancária surgiram do trabalho conjunto da UNEPFI e 30 bancos pioneiros, que lideraram o desenvolvimento dos Princípios para um Banco Responsável (PRB). Posteriormente, novas adesões permitiram consolidar os referidos princípios, aprovados na Roundtable de Paris e lançados em novembro de 2019 durante a Assembléia Geral anual da ONU, endossados por mais de 100 instituições do setor bancário internacional, incluindo 71 bancos e 40 outras instituições (PRB, 2020). Mais de 45 CEOs, e o Secretário-Geral da ONU, participaram da cerimônia de lançamento.

O lançamento consolidou a adesão de 190 bancos em mais de 60 países, representando cerca de $U \$ 50$ trilhões em ativos, em torno dos PRB, que consistem em seis diretrizes harmonizadoras e orientadoras para que as instituições financeiras do mundo incorporem a sustentabilidade em todas as áreas de seus negócios, definindo padrões para compreensão dos aspectos ambientais, sociais e de governança, nivelando-os à importância dos aspectos econômicos e financeiros nas atividades e negócios dos bancos (UNEPFI).

Esses princípios fornecem a estrutura para um sistema bancário sustentável e ajudam o setor bancário a demonstrar como faz uma contribuição positiva para a sociedade (NWOYE, 2020). 0 autor sugere que a principal razão apresentada aos bancos para serem signatários dos Princípios do UNEPFI é o suporte para aproveitarem a oportunidades de negócios nesta era de desenvolvimento sustentável e gerenciem os riscos emergentes do novo ambiente operacional. 
Esse contingente de instituições financeiras representa mais de um terço do setor bancário global, que se compromete com a responsabilidade social e a mudança para um futuro no qual a comunidade bancária contribui positivamente para as pessoas e o planeta.

A UNEPFI considera que esta é uma jornada de escala e escopo sem precedentes em um momento em que essa ambição é urgentemente necessária. Os bancos signatários do PRB comprometem-se a alinhar seus negócios com metas ambiciosas que contribuem para as metas globais e nacionais de sustentabilidade, com a formalização de compromissos e revisão anual de seu progresso individual em três etapas principais, que lhes permitem melhorar continuamente seu impacto e contribuição para a sociedade: i) Análise de impacto atual nas pessoas e no planeta; ii) Definição e Implementação de metas onde elas tenham o impacto mais significativo; e iii) Informação sobre o progresso das metas implantadas.

Um órgão consultivo da sociedade civil responsabilizará os signatários pelo seu progresso coletivo. Os Princípios para um Banco Responsável estão no Quadro 3, a seguir:

\section{Quadro 3: Princípios para um Banco Responsável (PRB)}

\begin{tabular}{|c|c|}
\hline Princípios & Especificação \\
\hline Alinhamento & $\begin{array}{l}\text { Alinharemos a estratégia de negócios para ser consistente e contribuir com necessidades das } \\
\text { pessoas e objetivos da sociedade, conforme os Objetivos de Desenvolvimento Sustentável, } \\
\text { Acordo Climático de Paris e estruturas nacionais e regionais relevantes. }\end{array}$ \\
\hline $\begin{array}{l}\text { Impacto e } \\
\text { estabelecimento de } \\
\text { metas }\end{array}$ & $\begin{array}{l}\text { Aumentaremos continuamente nossos impactos positivos, reduzindo impactos negativos e } \\
\text { gerenciando riscos para as pessoas e o ambiente resultantes de nossas atividades, produtos e } \\
\text { serviços. Para esse fim, definiremos e publicaremos metas nas quais possamos ter os impactos } \\
\text { mais significativos. }\end{array}$ \\
\hline Clientes consumidores & $\begin{array}{l}\text { Trabalharemos com responsabilidade com nossos clientes e consumidores para incentivar } \\
\text { práticas sustentáveis e permitir atividades econômicas que criem prosperidade compartilhada } \\
\text { para as gerações atuais e futuras }\end{array}$ \\
\hline Partes Interessadas & $\begin{array}{l}\text { Consultaremos, de forma proativa e responsável, participaremos e faremos parceria com as } \\
\text { partes interessadas relevantes para atingir os objetivos da sociedade. }\end{array}$ \\
\hline Governança e Cultura & $\begin{array}{l}\text { Implementaremos nosso compromisso com esses Princípios por meio de governança eficaz e } \\
\text { uma cultura de bancos responsáveis }\end{array}$ \\
\hline $\begin{array}{l}\text { Transparência e } \\
\text { Responsabilidade }\end{array}$ & $\begin{array}{l}\text { Revisaremos periodicamente nossa implementação individual e coletiva desses Princípios e } \\
\text { seremos transparentes e responsáveis por nossos impactos positivos e negativos e por nossa } \\
\text { contribuição para os objetivos da sociedade }\end{array}$ \\
\hline
\end{tabular}

\section{Fonte: https://www.unepfi.org/banking/banking/}

A prática dos bancos signatários de PRB se alinha com a visão que a sociedade estabeleceu para o futuro nos Objetivos de Desenvolvimento Sustentável e no Acordo do Clima de Paris. Ambos incorporam a sustentabilidade nos níveis estratégico, de portfólio e transacional, e demais áreas de negócios. Assim, os PRB estão em consonância com os fatores ESG, que podem criar riscos para bancos, investimentos e seguros e devem refletir transparência para produtos e serviços e criar valor para clientes, investidores e sociedade. 


\section{METODOLOGIA}

O estudo propõe responder à pergunta: Quais iniciativas institucionais refletem a responsabilidade social de entidades financeiras durante a pandemia? Assim, busca analisar as iniciativas institucionais que refletem a responsabilidade social de entidades financeiras, nas diversas regiões do mundo, direcionadas aos seus clientes e demais stakeholders, como suporte prestado e investimentos sociais no âmbito de sua atuação durante a pandemia, expressas na forma de investimentos responsáveis e finanças sociais. Para tanto, buscou explorar o perfil do setor financeiro, no mundo, de modo a mapear entidades com essas práticas.

O estudo aborda as empresas do setor de serviços financeiros que i) aderem às estruturas de financiamento sustentável quanto aos princípios do setor financeiro global; ii) que aderem às pautas de sustentabilidade da ONU; e iii) que estão listadas como membros UNEPFI. Tais instituições foram tomadas como população-alvo do estudo e estão classificadas como agências de investimentos, bancos e seguradoras, aderindo também às diretrizes de finanças sustentáveis e investimentos responsáveis, mediante a participação em coalizão de entidades comprometidas com a RS ao assumir os PRB.

Assim, a população-alvo se refere a todas as instituições financeiras que aderem a UNEPFI na data do estudo, correspondendo a 324 instituições membros localizados em mais de 60 países. Da populaçãoalvo, foram segregadas aquelas que aderem aos PRB (i.e., signatárias) e as que não aderiram (i.e., nãoSignatárias), como dois grupos para comparação.

Os procedimentos adotados como técnica de levantamento de dados envolvem mapeamento, registro e mensuração das entidades que fizeram ou não as contribuições para a sociedade, com a realização de ações de RS e investimento social durante a Pandemia Covid-19 e para quais beneficiários foram direcionadas tais contribuições.

Quanto ao objetivo, a pesquisa é exploratória e descritiva, pois relata características do setor e ações de RS a partir do modelo das diretrizes de finanças sustentáveis e investimentos responsáveis a partir Princípios da Responsabilidade Bancária (PRB-UNEP/FI 2019), bem como nos Princípios de Investimento Responsável (PRI/UNEPFI) e Fatores ESG (ESG/2018).

Quanto ao tempo é um estudo transversal, realizado de agosto a novembro de 2020, utilizando fontes secundárias obtidas na base documental que contém os cadastros de instituições financeiras que aderem ao UNEPFI e coalizões formadas por essas empresas.

O estudo é quantitativo, pois pretende responder os objetivos a partir das métricas, pertinentes aos dados cujas variáveis estão a seguir: a) Proveniência por região: continente, país; b) Tipo de atividade da Instituição Financeira; c) Status de signatárias ou não-signatárias dos PRB; d) Status de Contribuição 


\section{Gestãoe \\ Desenvolvimento}

e-ISSN: 2446-6875

p-ISSN: $1807-5436$

com ações de RS ou não-contribuição à sociedade durante a pandemia; e) Beneficiários, ou seja, MPEs, funcionários, clientes em geral, stakeholder, e públicos específicos; f) Doações em dinheiro; e g) Ações RS realizadas.

A análise quantitativa dos dados foi feita com uso de estatística descritiva com ênfase na distribuição dos dados. A análise dos dados teve apoio do software SPSS nas técnicas de exploração, chi-quadrado e tabulação cruzada, fornecendo outputs para descrição.

A pesquisa testa a divergência ou convergência das ações quanto às iniciativas de finanças sustentáveis e investimentos responsáveis entre instituições signatárias e não-signatárias dos PRB. Para tanto, foi adotado o teste chi-quadrado para comparar a ações estudadas mediante frequência. 0 teste analisa a hipótese nula de não haver discrepância entre as frequências observadas de um evento em confronto com as frequências esperadas, aplicado a situações com variáveis qualitativas com duas ou mais categorias e consiste em uma tabela de dupla entrada de linhas e colunas (BRUNI, 2008). A hipótese nula é testada mediante comparação de valor esperado e observado. Quando esses valores são muito diferentes ao nível de significância escolhido então se conclui que há evidências contra a hipótese nula e a hipótese alternativa é confirmada, ou seja, confirma relação entre as variáveis estudadas.

Considerando que as entidades declaram sua responsabilidade nos investimentos e aderem aos PRB é esperado pelo menos dois terços das empresas tenham dado suporte à sociedade durante o covid19. As hipóteses do estudo estão a seguir:

\begin{tabular}{|c|c|}
\hline & Quadro 4: Hipóteses do Estudo \\
\hline Hipótese & Descrição \\
\hline \multirow{2}{*}{ Hipótese 1} & $\begin{array}{l}\text { H1: Existe divergência entre os grupos de instituições financeiras que aderem ao UNEPFI dependendo } \\
\text { se são signatários ou não-signatárias do PRB. }\end{array}$ \\
\hline & $\begin{array}{l}\text { Ho: A hipótese nula estabelece que todos os grupos listados na UNEPFI estão igualmente engajados } \\
\text { com pautas de sustentabilidade independendo se são signatários dos PRB. }\end{array}$ \\
\hline \multirow{2}{*}{ Hipótese 2} & $\begin{array}{l}\text { H2: Existe divergência entre os grupos de instituições financeiras que aderem ao UNEPFI e atuaram na } \\
\text { Covid-19 dependendo se são signatários ou não-signatárias do PRB. }\end{array}$ \\
\hline & $\begin{array}{l}\text { Ho: A hipótese nula é de que os grupos de instituições que aderem ao UNEPFI e atuaram na Covid-19 } \\
\text { estão igualmente engajados independente de serem signatários ou não do PRB. }\end{array}$ \\
\hline \multirow{2}{*}{ Hipótese 3} & $\begin{array}{l}\text { H3: Existe divergência nos grupos de instituições financeiras listados na UNEPFI que contribuem com a } \\
\text { sociedade em suporte à Covid-19, dependendo da região de origem }\end{array}$ \\
\hline & $\begin{array}{l}\text { HO: A hipótese nula é de que todos os membros listados na UNEPFI signatários do PRB contribuem } \\
\text { com a sociedade em suporte à Covid-19, independentemente da região de origem. }\end{array}$ \\
\hline
\end{tabular}

\section{Fonte: elaboração dos autores}




\section{Gestãoe \\ Desenvolvimento}

e-ISSN: 2446-6875

p-ISSN: $1807-5436$

Ainda, uma análise qualitativa adotou técnica comparativa dos dados de perfil entre signatários e não-signatários dos PRB, que tenham contribuído com iniciativas de RS, verificando o teor dos princípios de investimento e de responsabilidade bancária nas suas ações e investimentos em articulação com características do perfil das entidades, por país, região e beneficiários atendidos. A pesquisa utiliza categorização das iniciativas de RS como variáveis selecionadas por ação e público-alvo sendo verificado o suporte destinado a MPE, clientes, funcionários; stakeholders (e.g. fornecedores, setor financeiro e demais setores empresariais, acionistas, comunidade); públicos específicos e doações em dinheiro.

\section{RESULTADOS E ANÁLISE}

A partir dos dados levantados e da análise das 324 instituições financeiras listadas na UNEPFI, foi identificada a presença de entidades aderentes em todas as regiões do mundo. Considerados os continentes, a maior parte está no continente europeu (46\%) seguida da América Latina (16\%) e a menor participação está na Oceania (3\%), conforme Gráfico 1.

Quanto ao tipo de atividade das instituições financeiras, os resultados mostraram a presença de bancos, agências de investimentos e seguradoras em todos os continentes, prevalecendo a atividade de bancos (65\%) em todas as regiões, conforme Gráfico 2.

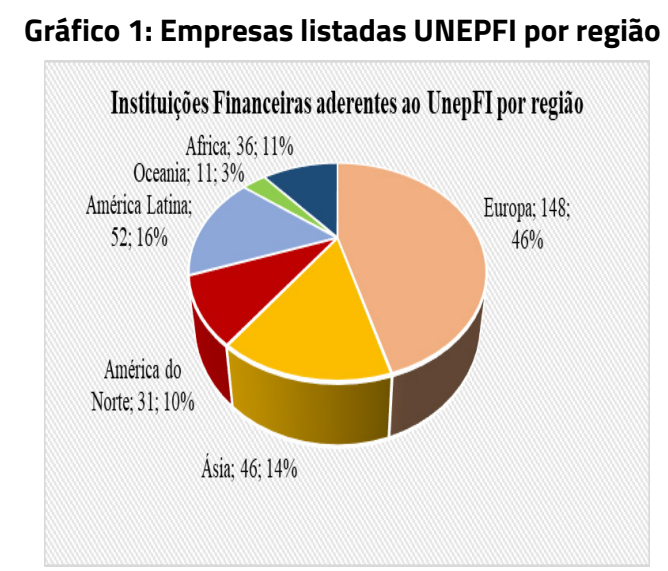

Fonte: Análise de dados
Gráfico 2: Empresas listadas UNEPFI por atividade

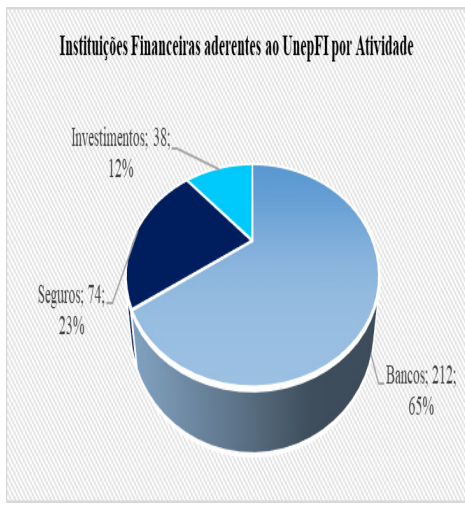

Fonte: Análise de dados

No tocante à divulgação, 143 empresas (44,1\%) estão listadas no GRI e, em 2019, submeteram 1.032 relatórios contendo 4.684 páginas de divulgação de suas práticas de RS em relatórios de sustentabilidade. Quanto aos membros que aderem ao PRB, 187 (58\%) são signatárias, o que demonstra o engajamento de um contingente representativo de instituições financeiras com as diretrizes de RS e sustentabilidade, conforme Gráfico 3. 


\section{Gestãoe \\ Desenvolvimento}

e-ISSN: 2446-6875

p-ISSN: 1807-5436

Gráfico 3: Empresas que aderem ao PRBI por região

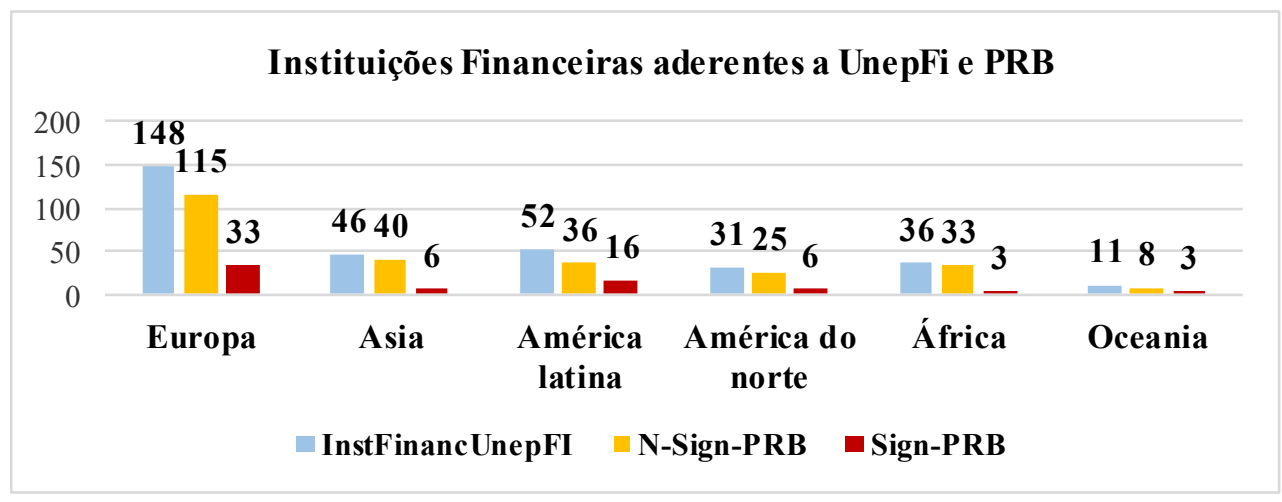

\section{Fonte: Análise de dados}

Os resultados da estatística descritiva mostraram que as instituições financeiras atuaram na crise da Covid19 com iniciativas de RS e suporte à comunidade de clientes e demais stakeholders. Contudo, o contingente identificado corresponde apenas a $21 \%$ das instituições listadas no UNEPFI, sendo todas aderentes aos PRB, e com presença detectada em todos os continentes. Desse modo, tem-se 324 Instituições listadas no UNEPFI, das quais 187 (58\%) aderem ao PRB, de modo que 67 (21\%) com atuação na crise do Covid19. Não houve atuação em 257 (79\%) instituiç̧ões não aderentes ao PRB. Conforme Gráficos 4 e 5.

\section{Gráfico 4: Empresas Signatárias do PRB}

Membros UNEPFI que aderem ao PRB

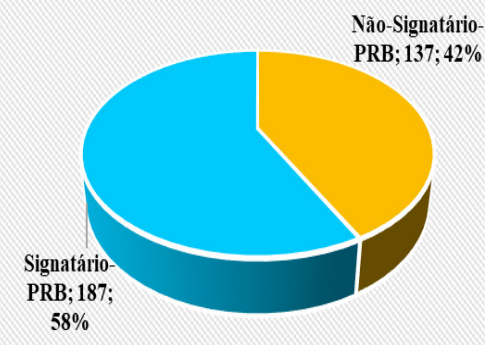

Fonte: Dados documentais UNEPFI/2020
Gráfico 5: Empresas Atuantes na Covid-19

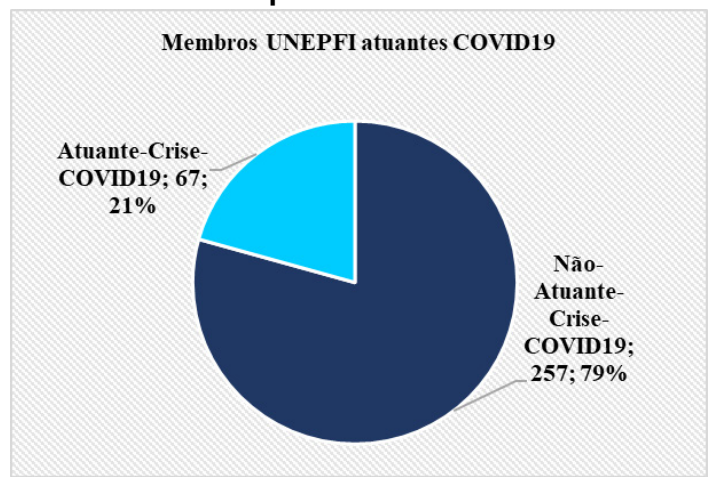

Fonte: Dados documentais UNEPFI/2020

Observa-se, assim, que há diferença nas frequências, mas há necessidade de verificar se possui significância estatística. A hipótese $\mathrm{H} 1$ presume a existência de divergência entre os grupos das instituições financeiras que aderem ao UNEPFI dependendo se são signatárias ou não do PRB. A estatística descritiva mostra $42 \%$ de não-signatários e $58 \%$ signatários. O teste qui-quadrado rejeitou a hipótese nula e mostra 


\section{Gestãoe \\ Desenvolvimento}

e-ISSN: 2446-6875

p-ISSN: $1807-5436$

que as frequências divergentes são significativas, o que é confirmado pela diferença entre valor observado e esperado com significância estatística, conforme Tabelas 1 e 2. Assim, há diferença entre os grupos confirmando a Hipótese 1.

Tabela 1 - Status Signatário

\begin{tabular}{cccc}
\hline Status & Observed N & Expected N & Residual \\
\hline Não-signatário PRB & 137 & 97,2 & 39,8 \\
Signatário PRB & 187 & 226,8 & $-39,8$ \\
Total & 324 & & \\
\hline
\end{tabular}

Fonte: Análise de dados

Tabela 2 - Chi-Square Tests

\begin{tabular}{|c|c|c|c|c|c|}
\hline \multirow[t]{3}{*}{ Status } & \multirow[t]{3}{*}{ Value } & \multirow[t]{3}{*}{ df } & \multirow{3}{*}{$\begin{array}{l}\text { Asymp. Sig. } \\
\text { (2-sided) }\end{array}$} & \multicolumn{2}{|c|}{ Monte Carlo Sig (2-sided) } \\
\hline & & & & \multicolumn{2}{|c|}{ Sig $99 \%$ ConfidenInterval } \\
\hline & & & & LowerBound & UpperBound \\
\hline $\begin{array}{c}\text { Pearson Chi- } \\
\text { Square }\end{array}$ & $14,425^{*}$ & 5 & 013 & 011 & 39,8 \\
\hline Likelihood Ration & 14,406 & 5 &, 013 &, 013 & $-39,8$ \\
\hline
\end{tabular}

Teste de aderência. a. 1 cells $(8,3 \%)$ have expected count less than 5. The minimum expected count is 4,65.

b. Based on 10000 sampled tables with starting seed 607812888.

\section{Fonte: Análise de dados}

A Hipótese 2 presume que há divergências entre os grupos de instituições financeiras que aderem a UNEPFI e atuaram na Covid19, dependendo se são signatários ou não do PRB. A estatística descritiva mostrou que, dos 324 membros UNEPFI, 58\% são signatários dos PRB, e apenas 21\% atuaram na crise do Covid19 com ações equivalentes a investimentos responsáveis, oferta de produtos sociais e auxílios para seus públicos e comunidade de entorno. $\mathrm{O}$ teste do Chi-quadrado demonstra que a divergência nas frequências é significativa e evidencia a atuação dos signatários-PRB na crise. Igualmente, o teste evidencia a ausência de ação dos não signatários e essa afirmação tem significância estatística de 99\% de certeza, conforme Tabela 3.

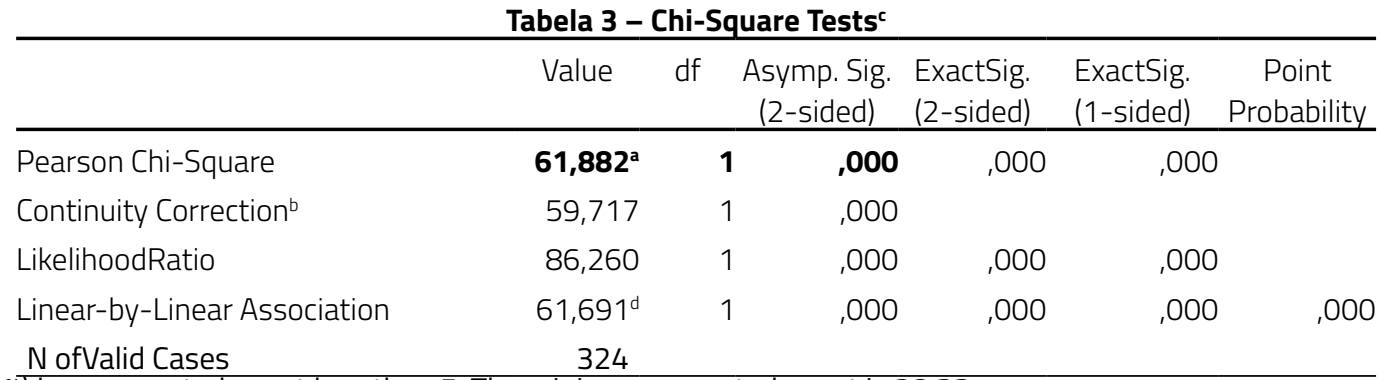

a. 0 cells $(0,0 \%)$ have expected count less than 5 . The minimum expected count is 28,33 .

b. Computed only for a $2 \times 2$ table; c. For $2 \times 2$ crosstabulation, exact results are provided instead of Monte Carlo results; $d$. The standardized statistic is 7,854 .

\section{Fonte: Análise de dados}




\section{Gestãoe \\ Desenvolvimento}

e-ISSN: 2446-6875

p-ISSN: $1807-5436$

A Hipótese 3 presume que existe divergência nos grupos de instituições financeiras listados na UNEPFI, que contribuem com a sociedade em suporte ao Covid19, dependendo da região/continente de onde são provenientes. A estatística descritiva apresenta diferenças entre os grupos, contudo o teste Qui-quadrado não permite rejeitar a hipótese nula, pois não há significância estatística na frequência das diferenças apresentadas, conforme Tabela 4. Isso significa que não houve divergência nas contribuições e apoio à sociedade prestados por instituições financeiras signatárias dos PRB no período da Pandemia Covid19.

Tabela 4 - Chi-Square Tests

\begin{tabular}{ccccccc}
\hline Chi-Square Tests & Value & df & $\begin{array}{c}\text { Asymp. Sig. } \\
\text { (2-sided) }\end{array}$ & Sig. & $\begin{array}{c}\text { Monte Carlo Sig. (2-sided) } \\
\text { 99\% Confidencelnterval } \\
\text { LowerBound }\end{array}$ & UpperBound \\
\hline Pearson Chi-Square & $\mathbf{8 , 7 6 9 ^ { \mathrm { a } }}$ & $\mathbf{5}$ & $\mathbf{, 1 1 9}$ & $\mathbf{, 1 4}^{\mathrm{b}}$ & $\mathbf{, 1 0 6}$ &, $\mathbf{1 2 2}$ \\
LikelihoodRatio & 9,375 & 5 &, 095 &, $109^{\mathrm{b}}$ &, 101 &, 117 \\
N ofValid Cases & 324 & & & & & \\
\hline
\end{tabular}

\section{Fonte: Análise de dados}

É possivel apontar algumas diferenças que merecem destaque quando se observa o valor do resíduo na tabela de cálculo do Qui-quadrado, que superou -1,96 ou 1,96 em quase todos os continentes, exceto pela Ásia e África, que tiveram peso na rejeição da hipótese. Esses resultados serão detalhados nos dados qualitativos da análise comparativa.

A análise das iniciativas de RS realizadas pelas instituições financeiras como apoio aos clientes e demais stakeholders durante o período da pandemia permitiu observar, para além do quantitativo, uma variedade de iniciativas. Ao percorrer os feitos em cada país e nos continentes, acaba-se por identificar convergências entre as práticas e peculiaridades regionais no atendimento de necessidades da sociedade e comunidade.

Assim, foram analisadas tais iniciativas por categoria e por tipo de beneficiário ou destinatário, mostrando que as ações podem ser classificadas como iniciativas de finanças sociais, pois se direcionam a negócios de impacto, ou iniciativas que usam mecanismos financeiros para gerar impacto social com sustentabilidade financeira (FTFS, 2018).

No tocante às iniciativas direcionadas, as maiores contribuições, ocorreram no apoio as MPEs, aos seus funcionários, aos clientes em geral e outros stakeholder, bem como foram identificadas doações em dinheiro.

As iniciativas de RS das instituições engajaram 40 bancos em 32 países, de todas as regiões de mundo, para suporte a MPE. As principais iniciativas tratam da flexibilização de obrigações financeiras, 
como reestruturação de dívidas com moratória, congelamento de juros e treinamento para MPEs funcionarem com atendimento online, conforme Quadro 5.

Quadro 5 - Iniciativas de RS direcionadas aos micro e pequenos empreendimentos durante a Pandemia

\begin{tabular}{|c|c|}
\hline Região & Iniciativas direcionadas aos micro e pequenos empreendimentos \\
\hline Europa & $\begin{array}{l}\text { A ajuda da Europa às MPEs foi identificada em } 13 \text { países (Alemanha, Bélgica, Espanha, Finlândia, } \\
\text { França, Grécia, Holanda, Irlanda, Itália, Noruega, Reino Unido, Rússia e Suíça) por meio de } 22 \text { Instituições } \\
\text { Financeiras. As principais ações consistiram em Moratória no pagamento das dívidas, Diferimento de saldo } \\
\text { devedor, isenção de taxas de amortização e juros, aporte de recursos em financiamentos para capital de } \\
\text { giro, a maior parte condicionada à manutenção dos empregos. Ressalta-se a alocação orçamentária de } \\
\text { grande vulto nos bancos da Espanha, com uma soma de grande materialidade no valor de } € 78,3 \text { bilhões } \\
\text { pelos bancos BBVA (25) Santander (20) Caixa Bank }(25) \text { e Abanca }(8,3) \text { destinada aos pequenos negócios } \\
\text { e profissionais autônomos e o Banco UBS da Suiça que alocou } 1 \text { bilhão de francos suiços para liquidez a } \\
\text { 10.000 PME }\end{array}$ \\
\hline Oceania & $\begin{array}{l}\text { A ajuda da Oceania às MPEs foi identificada em apenas } 2 \text { bancos na Austrália, único país com adesão a } \\
\text { UNEPFI. Ações como moratória de até } 6 \text { meses em dívidas no Westpac e Common wealth Bank. Destaque } \\
\text { para o último, com aporte de US\$10 bi para linha de crédito as MPE. }\end{array}$ \\
\hline Ásia & $\begin{array}{l}\text { A ajuda da Ásia às MPEs foi identificada em apenas } 3 \text { países (China, Bangladesh e Malásia) por meio } \\
\text { de } 3 \text { Instituições Financeiras. As principais ações foram em alocação de empréstimos na China a } 14 \text { mil } \\
\text { empreendimentos, com aporte de } 43 \text { bilhões de Yuans (cerca de R } \$ 32,3 \text { bi). Na Malásia foi ofertado } \\
\text { treinamento para que PME funcionassem como lojas remotas. Em Bangladesh, houve flexibilização para } \\
\text { empréstimos online. }\end{array}$ \\
\hline África & $\begin{array}{l}\text { A ajuda da África às micro e pequenas empresas foi identificada em } 6 \text { países (África do Sul, Egito, Namíbia, } \\
\text { Quênia, Botswana e Uganda) por meio de } 2 \text { Instituições Financeiras, o CIB - Comercial International Bank } \\
\text { e Standard Bank presente em } 5 \text { países. As principais ações consistiram em flexibilização de obrigações } \\
\text { financeiras paras MPE, como Reestruturação das dividas com Moratória, com suporte financeiro aos } \\
\text { funcionários das MPE clientes. Destaque para o CIB, no Egito, que concedeu perdão de } 50 \% \text { do valor das } \\
\text { dívidas e } 100 \% \text { no valor dos juros a inadimplentes com renegociações e criou um centro de contato e } \\
\text { atendimento online. }\end{array}$ \\
\hline $\begin{array}{l}\text { América } \\
\text { do Norte }\end{array}$ & $\begin{array}{l}\text { A ajuda da América do Norteàs micro e pequenas empresas foi identificada em apenas no Canadáem } 3 \\
\text { banscos. As principais ações consistiram em refinanciamento de dívidas, empréstimos para capital de giro } \\
\text { e atendimento online. }\end{array}$ \\
\hline $\begin{array}{l}\text { América } \\
\text { Latina }\end{array}$ & $\begin{array}{l}\text { A ajuda da América Latina e Caribe às micro e pequenas empresas foi identificada em } 6 \text { países (Brasil, } \\
\text { Colômbia, El Salvador, Equador, México e Panamá) por meio de } 8 \text { Instituições Financeiras. As principais } \\
\text { ações consistiram em Moratória no pagamento das dívidas, especificamente no Equador vias bancos } \\
\text { Guayaquil e Pichincha, no México (Citibanamex) e Panamá (Global Bank). No Brasil, apenas } 2 \text { bancos } \\
\text { realizaram ações com aporte de recursos destinados a financiar a folha de pagamento das empresas } \\
\text { (Bradesco) e consignado especial para as MPE (Itaú). A Colômbia (Bancolombia) congelou os juros e em El } \\
\text { Salvador (Banco Hipotecário) ofertou crédito para financiar capital de giro }\end{array}$ \\
\hline
\end{tabular}

\section{Fonte: Pesquisa documental}

As iniciativas junto aos clientes em geral, como suporte durante a pandemia, envolveram 43 bancos em 28 países de cinco continentes, excluindo apenas a região da Oceania, que não participou 
dessa iniciativa, e cujas principais contribuições trataram de oferta de crédito, moratória de empréstimos a clientes corporativos e pessoa física, com reescalonamento de dívidas, além da oferta de atendimento online, conforme Quadro 6.

Quadro 6 - Iniciativas de RS direcionadas aos clientes em geral durante a Pandemia

\begin{tabular}{|c|c|}
\hline Regiões & Iniciativas direcionadas aos clientes em geral \\
\hline Europa & $\begin{array}{l}\text { O Apoio aos clientes em geral foi identificado em } 14 \text { países (os citados mais a suécia) e } 28 \text { bancos. As ações } \\
\text { junto à clientelaforam representadas por ampla oferta decrédito, moratória deempréstimos, especialmente } \\
\text { nas hipotecas, diferimento de dividas com redução de taxas vencidas. Observou-se que alguns bancos. } \\
\text { Ações que se destacaram referentes aos Bancos Espanha, BBVA que ofertaram adiantamentos de } \\
\text { seguro-desemprego aos seus clientes espanhóis e o Abanca, que, além do adiantamento desemprego } \\
\text { ofertou linha de empréstimos a clientes especialmente impactados com a Covid-19. Na Holanda o Banco } \\
\text { ING ofertou serviços de consultoria financeira. Na França os Bancos BNP Paribas e Societé Generale e na } \\
\text { Suíça o Credit-Suisse ofertaram financiamentos com garantia pelos seus governos. }\end{array}$ \\
\hline Ásia & $\begin{array}{l}\text { Apoio aos clientes foi identificado em } 4 \text { países e } 5 \text { bancos. As ações junto à clientela foram representadas } \\
\text { por oferta de crédito, moratória de empréstimos, reescalonamento de dividas e facilidades de atendimento } \\
\text { online inclusive para contratar empréstimos. Observou-se que na China o HuaXia Bank procedeu à } \\
\text { sanitização sistemática das cédulas de dinheiro e na Coréia do Sul O KB Financial Group odereceu } \\
\text { consultoria financeira aos seus clientes. }\end{array}$ \\
\hline África & $\begin{array}{l}\text { O Apoio aos clientes em geral foi identificado em } 5 \text { países e } 2 \text { bancos. Ações junto à clientela foram } \\
\text { representadas por oferta de crédito, moratória de empréstimos a clientes corporativos e pessoa física, } \\
\text { reescalonamento de dividas em condições individuais. Destaca-se ação na Uganda: Standard Bank } \\
\text { promoveu acesso a importação de produtos provenientes de fornecedores chineses }\end{array}$ \\
\hline $\begin{array}{l}\text { América } \\
\text { do Norte }\end{array}$ & $\begin{array}{l}\text { O Apoio aos clientes em geral foi identificado em } 2 \text { países e } 5 \text { bancos. Ações junto à clientela incluíram } \\
\text { isenção de taxas de transações, prorrogação de prazos de vencimentos, deferimento de empréstimos. } \\
\text { Destaque para o Banco Desjardins no Canadá, com suporte a seguro-viagens para que pessoas retornarem } \\
\text { ao país no início da Pandemia, apoio psicológico e jurídico }\end{array}$ \\
\hline $\begin{array}{c}\text { América } \\
\text { Latina }\end{array}$ & $\begin{array}{l}\text { O Apoio aos clientes em geral foi identificado em } 8 \text { países (Brasil, Colômbia, Costa Rica, El Salvador, } \\
\text { Equador, México, Panamá e Paraguai) e } 16 \text { bancos, entre este a CAF, corporação Andina de Fomento, } \\
\text { entidade transnacional. As ações junto à clientela foram representadas por ampla moratória no pagamento } \\
\text { das dívidas com diferenciação de prazos, diferimento de parcelas, congelamento de juros em hipotecas, } \\
\text { Reestruturação de dividas e renegociação no financiamento inadimplente de bens e cartões de crédito. } \\
\text { Destaque para linha de crédito emergencial pela CAF com aporte de recursos de U\$2,5bi operacional e a } \\
\text { recuperação econômica das empresas latino-americanas em geral e lançamento do fundo de assistência } \\
\text { técnica de US \$ } 5 \text { milhões aberto a países membros para ajudar na execução dos Planos Nacionais de } \\
\text { Emergência de Coronavírus. }\end{array}$ \\
\hline
\end{tabular}

\section{Fonte: Pesquisa documental}

As iniciativas de RS junto aos seus funcionários engajaram apenas 3 regiões, quais sejam Europa e as Américas do Sul e do Norte, contemplando home office para funcionários de retaguarda bancária e ajustes para os que não puderam dispensar o atendimento presencial. Além disso, foi feito o congelamento de demissões e a compensação salarial, sendo envolvidos apenas 9 bancos em 7 países, conforme Quadro 7. 


\section{Gestãoe \\ Desenvolvimento}

e-ISSN: 2446-6875

p-ISSN: $1807-5436$

Quadro 7 - Iniciativas de RS direcionadas aos Funcionários e Terceirizados dos Bancos durante a Pandemia

\begin{tabular}{|c|l|}
\hline Região & \multicolumn{1}{c|}{ Iniciativas direcionadas aos Funcionários e Terceirizados dos Bancos } \\
\hline Europa & $\begin{array}{l}\text { As ações dedicadas aos funcionários dos Bancos da Europa foram encampadas apenas por } 6 \text { bancos } \\
\text { e em } 4 \text { países (Alemanha, Espanha, França e Holanda. As ações consistiram em medidas bastante } \\
\text { diversificadas: Na Alemanha o Deutsche Bank incentivou funcionários a apoiar instituições de caridade } \\
\text { que abrigassem vulneráveis. Na Espanha o Abanca viabilizou apoio financeiro e o Caixa Bank alterou } \\
\text { turnos de trabalho e deu ênfase ao trabalho remoto quando possível. Na Holanda o ING também } \\
\text { adotou trabalho remoto. Na França O BNP Paribas treinou seu pessoal para emergência junto as PME } \\
\text { e o societéGenerale garantiu salários para } 140 \text { mil funcionários e implantou programa de solidariedade } \\
\text { global junto a idosos e vulneráveis }\end{array}$ \\
\hline América do \\
Norte & $\begin{array}{l}\text { As ações dedicadas aos funcionários dos Bancos da América do Norte foram encampadas por apenas } \\
\text { ajuste de horários de linha de frente, com redução de jornada e do sábado de atendimento ao público. O } \\
\text { Citi fez congelamento de demissões. Nos EUA oferta de US\$ 1000 para funcionários com salário menor } \\
\text { que U\$ 60 mil anuais. Ofereceu prêmio de compensação especial a Mais de 75.000 funcionários em todo } \\
\text { o mundo como ajuda para aliviar encargos financeiros da pandemia de corona vírus. }\end{array}$ \\
\hline $\begin{array}{c}\text { América } \\
\text { Latina }\end{array}$ & $\begin{array}{l}\text { As ações dedicadas aos funcionários dos Bancos da américa Latina foram realizadas apenas pelo Banco } \\
\text { Diners Club Del Ecuador que iniciou treinamento em finanças para seu pessoal,estendendo à comunidade } \\
\text { de usuários do Banco. }\end{array}$ \\
\hline
\end{tabular}

Fonte: Pesquisa documental

Já no tocante às iniciativas de RS direcionadas a outros Stakeholders como acionistas, fornecedores e alguns públicos específicos da comunidade do seu entorno foram observadas iniciativas de 21 instituições financeiras em 15 países, em quatro principais principais regiões, ou seja, Europa, Ásia, África e América Latina voltadas a fornecedores, populações vulneráveis, equipes médicas e outros públicos das comunidades, conforme Quadro 8. 


\section{Gestãoe \\ Desenvolvimento}

e-ISSN: 2446-6875

p-ISSN: 1807-5436

\begin{tabular}{|c|c|}
\hline Regiões & Iniciativas direcionadas aos outros stakeholders \\
\hline Europa & $\begin{array}{l}\text { Quanto as ações direcionadas a outros públicos das Instituições Financeiras, verificou-se iniciativas em } \\
\text { apenas } 6 \text { países e } 9 \text { bancos. Os demais stakeholder envolvidos foram: } \\
\text { Acionistas, que tiveram cancelamento do pagamento de dividendos de } 2019 \text { nos bancos KVC (Bélgica) } \\
\text { e Unicredi (Itália) e esses bancos adiaram as recompras de ações. Fornecedores, que receberam } \\
\text { crédito para financiamento, moratória em dividas e em caso específico na Espanha, o Bankia manteve } \\
\text { remuneração de fornecedores mesmo sem serviços, condicionada à manutenção dos empregos. } \\
\text { Governo como fornecedor na Espanha, recebeu do Santander a quantia f } 5 \text { milhões em equipamentos } \\
\text { tomógrafos e respiradores além da realização de exames } \\
\text { Comunidade - No Reino Unido o Standard Chartered Bank alocou US\$ } 50 \text { millhões destinado à } \\
\text { assistência imediata e no socorro pós-pandemia }\end{array}$ \\
\hline Ásia & $\begin{array}{l}\text { As ações direcionadas a outros públicos das Instituições Financeiras, verificou-se iniciativas em apenas } \\
2 \text { países e } 4 \text { bancos. Os demais stakeholder envolvidos foram: Comunidade - em Bangladesh, que } \\
\text { recebeu do IBLC Bank apoio básico e de saúde, um programa alimentar destinado a } 7.500 \text { famílias. Na } \\
\text { China o China Industria Bank forneceu serviços médicos via plataforma e lançou título de mercado para } \\
\text { obter recursos voltados à prevenção da epidemia. }\end{array}$ \\
\hline África & $\begin{array}{l}\text { As ações direcionadas a outros públicos das Instituições Financeiras, verificou-se apenas no Egito, onde } \\
\text { CIB promoveu treinamento remoto e educação financeira digital a comunidade para acesso aos canais } \\
\text { do Banco. Para isso foi usado You Tube e Facebook. Na África do Sul foi prorrogado recebimento de } \\
\text { dívidas de estudantes e ONG pelo Standard Bank; No Quênia o governo desembolsou recursos via KCB } \\
\text { Group criando fundo destinado a socorrer vulneráveis }\end{array}$ \\
\hline $\begin{array}{c}\text { América } \\
\text { Latina }\end{array}$ & $\begin{array}{l}\text { As ações direcionadas a outros públicos das Instituições Financeiras, no Brasil verificou-se iniciativas em } \\
\text { apenas } 2 \text { bancos e } 1 \text { país, Os demais stakeholder envolvidos foram os outros bancos do setor bancário } \\
\text { no país. O Bradesco realizou Coligação com bancos p/ doar } 5 \text { milhões de testes rápidos e equipamentos } \\
\text { médicos (máscaras de proteção, tomógrafos e respiradores) ao governo brasileiro. O Bradesco fez } \\
\text { também coligação c/ hospitais privados para construir um hospital de campanha e apoiar governo } \\
\text { Estadual. O Itaú fez ação conjunta com outros bancos para alocar R } \$ 50 M M \text { para a compra de } 15 \\
\text { milhões de máscaras, produzidas por MPE e fez doação de } 5 \text { milhões de testes Covid-19. O citibanamex } \\
\text { alocou } 105 \text { milhões de pesos (US } \$ 4,5 M M \text { ) para apoiar pessoas vulneráveis. Banco Guayaquil destinou } \\
\text { US\$1 milhão em iniciativas para alimentação de vulneráveis, compra de equipamentos médicos p/ à } \\
\text { emergência sanitária, respiradores e UTI. CAF - linha de crédito de US } \$ 300 \text { milhões para lidar com o } \\
\text { surto, fornecendo US } \$ 50 \text { milhões a cada país membro para apoiar os sistemas de saúde locais }\end{array}$ \\
\hline
\end{tabular}

\section{Fonte: Pesquisa documental}

Ainda se registra uma importante contribuição realizada por 14 grandes bancos ao redor do mundo, presentes em 10 países, representada pela doação de quantias vultosas em dinheiro. As iniciativas na Europa são equivalentes ao montante de 5 bilhões de euros, destinados aos seus programas sociais e comunidades médicas e centros de pesquisa voltadas à luta contra a pandemia. Na América Latina foram doados US\$ 40 milhões de dólares direcionados aos profissionais de saúde, suprimentos médicos e educação às crianças em áreas rurais. Na Ásia e África as contribuições alcançaram, respectivamente, US\$ 13,2 e 2,78 milhões de Dólares focados na Pandemia, em materiais e fundo de emergência para apoiar 


\section{Gestãoe \\ Desenvolvimento}

e-ISSN: 2446-6875

p-ISSN: $1807-5436$

as comunidades. Por fim, a América Latina teve US $\$ 40$ milhões de recursos em dinheiro direcionado para suprimentos médicos, equipes de saúde, programas institucionais de educação e empreendedorismo (e.g., UNICEF, educação básica e conectividade de populações longínquas), conforme Quadro 9.

Quadro 9 - Iniciativas de RS referente a doações em dinheiro durante a Pandemia

\begin{tabular}{|c|c|c|c|}
\hline País & Bancos & Doações em \$ & Tipo de doações \\
\hline Brasil & Itaú Unibanco & U\$ 27,7 milhões & $\begin{array}{l}\text { Profissionais da saúde ref. Produtos e parcerias projetados } \\
\text { exclusivamente para profissionais de saúde (por exemplo, 100\% } \\
\text { de desconto no seguro residencial }\end{array}$ \\
\hline \multirow[b]{2}{*}{ Equador } & Banco Pichincha & US \$10 milhões & Covid19 \\
\hline & $\begin{array}{l}\text { Banco Diners Club } \\
\text { del Ecuador }\end{array}$ & \$3 milhões & $\begin{array}{l}\text { Aliança Diners Unicef e do programa Edupasión- garantiu } \\
\text { suprimentos médicos. Apoio à educação e suporte à saúde; } \\
\text { apoiou } 88 \text { programas de televisão para oferecer educação básica } \\
\text { às crianças equatorianas, especialmente as do setor rural sem } \\
\text { acesso à Internet ( } 11 \% \text { ). }\end{array}$ \\
\hline Alemanha & Deutsche Bank & € 1,5 Milhão & $\begin{array}{l}\text { Global Peace Foundation; Henry Street; Cruz Vermelha Italiana E } \\
\text { Espanhola; Fareshare }\end{array}$ \\
\hline \multirow[t]{2}{*}{ Espanha } & BBVA & € 35 milhões & Luta contra o COVID-19 \\
\hline & Santander & $€ 4$ Milhões & Setor de saúde \\
\hline França & BNP Paribas & $€ 1$ milhão & Instituto Pasteur; hospitais \\
\hline \multirow[t]{2}{*}{ Irlanda } & AlB Groupplc, & $€$ 4,4 milhões & $\begin{array}{l}\text { Trinity College Dublin; Programa Investimento Comunitário; } F \text { Food } \\
\text { Cloud e Soar }\end{array}$ \\
\hline & Bank oflreland & $€ 1$ milhão & Instituições de caridade, vulneráveis Reino Unido \\
\hline \multirow[t]{2}{*}{ China } & $\begin{array}{l}\text { China Industrial } \\
\text { Bank, }\end{array}$ & U\$ 6,8 milhões & Pandemia COVID \\
\hline & HuaXia Bank, & U\$ 4,57 milhões & Pandemia COVID \\
\hline Egito & $\begin{array}{l}\text { Commercial } \\
\text { International Bank } \\
\text { (CIB), }\end{array}$ & $\begin{array}{l}\text { US } \$ 2,780 \\
\text { milhões }\end{array}$ & $\begin{array}{l}\text { 1) Fundo de Emergência e Crise; (2) fundo Tahya Misr } \\
\text { (LongliveEgypt); (3) fundo resposta à covid-19 da União Africana; } \\
\text { iniciativa liderada pela Federação de Bancos Egípcios em } \\
\text { coordenação com o Banco Central do Egito; para comprar } 100 \\
\text { kits de detecção RT-PCR para aumentar a capacidade de teste } \\
\text { para COVID-19 em todo o Egito; }\end{array}$ \\
\hline USA & Citi & US\$15 milhões & \\
\hline \multirow[t]{2}{*}{ Canadá } & $\begin{array}{l}\text { National Bank of } \\
\text { Canada }\end{array}$ & US $\$ 550.000$ & o banco apoia clientes idosos e faz contato para oferecer ajuda \\
\hline & Vancity & US \$ 200 milhões & $\begin{array}{l}\text { alocamos } 30 \% \text { do lucro líquido para membros e comunidades } \\
\text { impactados pelo COVID- } 19 \text {. }\end{array}$ \\
\hline
\end{tabular}

Fonte: Pesquisa documental 
Os resultados apresentados descrevem as iniciativas institucionais de entidades financeiras que refletem ações de RS declaradas durante a pandemia e representam os achados do presente estudo, respondendo seu questionamento.

Após os testes, foi possível aceitar as hipóteses 1 e 2 e estes resultados expõem diferenças significativas entre as iniciativas das instituições financeiras listadas no UNEPFI, mostrando que mesmo as empresas que aderem às pautas de sustentabilidade da ONU adotam práticas diferenciadas. Nesse sentido, destacam-se $21 \%$ das instituições financeiras, que se dispuseram a apoiar seus públicos por ocasião da crise da Covid-19 e adotaram iniciativas de responsabilidade social, durante o período da pandemia.

As ações foram direcionadas aos diversos públicos da sociedade, com destaque para micro e pequenos empreendimentos, clientela em geral na comunidade de atuação, bem como outros públicos específicos. Todas essas empresas são signatárias dos PRB e não foram identificadas iniciativas nas demais empresas não-signatárias.

Nesse sentido, é possivel afirmar que os PRB representaram mecanismo institucional catalizador de iniciativas de relevância, direcionados a atender à sociedade com uniformidade, independente da região de atuação da instituição financeira. Isso se mostra importante, pois reforça a aplicabilidade de tais princípios, além de sua viabilidade em diferentes contextos. Ademais mostra que além das agências de investimento e clientes do mercado, as instituições financeiras têm passado a integrar as pautas de sustentabilidade e suas práticas

Estudo da Bloomberg (MILLER; BALLIN, 2018) sinaliza a incorporação da sustentabilidade às estratégias das firmas com a integração de fatores ESG aos negócios, o que reflete no aumento das práticas de disclosure das firmas em relatórios de sustentabilidade. Como evidência, mostra que apenas 20\% das 500 empresas mais valiosas listadas no ranking da Standard \& Poors (S\&P 500) divulgavam suas ações em 2011. Já em 2017, 85\% passaram a divulgar práticas e publicar relatórios, com informações não financeiras.

Quanto à hipótese 3, os testes não confirmaram a existência de diferenças estatisticamente significativas entre as iniciativas de RS oriundas das Instituições Financeiras, quando consideradas por sua proveniência, tendo como base os diversos continentes onde se localizam as empresas. Mesmo não sendo consideradas divergentes, em termos estatísticos, o estudo buscou entender melhor a natureza de tais iniciativas nas diferentes regiões por meio de análises e comparações qualitativas. Assim, as ações identificadas foram categorizadas e analisadas nas diferentes regiões do mundo. Desse modo, as iniciativas são apresentadas na sequência, de acordo com cada região global. 
O continente europeu participa do UNEPFI com 148 bancos, dos quais 31 signatários do PRB apresentaram suas contribuições no período pandêmico em todos os itens observados e fizeram doações da ordem de $€ 5,07$ bilhões, e outras contribuições. As ações possuem compatibilidade com as características de finanças sociais e investimento de impacto.

A região Asiática adere ao UNEPFI com 46 bancos, e entre estes 6 signatários do PRB apresentaram contribuições no período em quase todos os itens observados exceto no tocante a outros stakeholders fizeram doações da ordem de US\$11,37milhões. As ações possuem convergência com as características de finanças sociais e com investimento de impacto.

A região Africana está no UNEPFI com 36 bancos, dos quais 8 signatários do PRB atuaram na crise Covid-19 em quase todos os beneficiários exceto funcionários. As doações corresponderam a US\$ 2,78 milhões, além de outras, mostrando compatibilidade com as características de finanças sociais e com investimento de impacto.

O continente Norte Americano participa do UNEPFI com 31 bancos, dos quais 5 signatários do PRB atuaram no período pandêmico junto aos beneficiários exceto no tocante aos outros stakeholder. As doações corresponderam a US\$765,78 milhões e contribuições convergentes com as características de finanças sociais e com investimento de impacto.

O continente Latino-Americano participa do UNEPFI com 52 bancos, dos quais 16 signatários do PRB contribuições no período pandêmico para todos os beneficiários, exceto outros stakeholder. As doações corresponderam a US\$40,7 milhões em dinheiro, além de outras contribuições convergentes com as características de finanças sociais e com investimento de impacto.

A região da Oceania participa do UNEPFI com 11 bancos, dos quais 4 signatários do PRB apresentaram suas contribuições no período pandêmico nos itens de clientes em geral e às MPE, mas não fizeram doações em dinheiro. Em que pese o fato de não contemplar outros itens, as ações identificadas possuem compatibilidade com as características de finanças sociais e com investimento de impacto.

Verificou-se que as regiões refletiram convergências quanto às iniciativas, tomadas pelas instituiç̧ões, contribuições e beneficiários, independentemente dos recursos e valor disponibilizado. Espera-se que haja maior aderência das empresas, até porque há espaço para engajamento de bancos, seguradoras e investidores às pautas globais de responsabilidade socioambiental. Ademais as iniciativas apresentadas no presente estudo indicam atuação de apenas 67(21\%) as instituições listadas no UNEPFI, todas elas aderentes aos PRB. Isso indica que ainda existe muito espaço para atuação das demais instituições, sendo isso uma demanda e uma tendência.

O World Economic Forum apresentou seu Relatório Global de Riscos evidenciando o confronto econômico e a turbulência geopolítica com retrocessos no multilateralismo, com alerta de risco global 
em curto prazo, agravado por questões socioambientais que ameaçam a sociedade no longo prazo. Isso aponta a necessidade de adotar nova estratégia econômica, mudar a forma de fazer negócios e empreender com respeito aos seres vivos, à natureza (WEF, 2020).

\section{CONSIDERAÇÕES FINAIS}

O presente trabalho teve como objetivo analisar as iniciativas institucionais que refletem a responsabilidade social de entidades financeiras, nas diversas regiões do mundo, direcionadas aos seus clientes e demais stakeholders, como suporte prestado e investimentos sociais no âmbito de sua atuação durante a pandemia.

Em seus resultados, o estudo descreve o perfil das empresas por tipo de atividade, proveniência e tipo de iniciativas durante a pandemia como suporte aos clientes em geral, funcionários, stakeholders, MPEs e públicos específicos. Além de comparar iniciativas em relação ao continente de origem, os bancos e analisar se a vinculação aos PRB afeta suas realizações. Foi possível constatar que existe diferença entre as amostras. Verificou-se que não há membros com atuação na crise da Covid-19 entre os nãoSignatários do PRB, o que reflete diferença entre práticas. A análise evidencia atuação dos signatáriosPRB na crise Covid-19. Por fim, indica que as instituições financeiras signatárias dos PRB contribuem igualmente com seu apoio à sociedade no período da Pandemia Covid-19, independentemente de suas regiões de proveniência, no mundo.

A pesquisa contribui com uma visão estruturada do setor financeiro que adere às diretrizes de finanças sustentáveis, descreve as iniciativas de RS por meio dos investimentos de impacto social realizados pelos signatários dos PRB durante a Covid-19 e evidencia certo engajamento de instituições financeiras com a responsabilidade social ao redor do mundo.

O estudo possui restrições por mostrar resultados quanto às iniciativas de instituições financeiras com ênfase no aspecto social. É compreensivel, por conta da crise pandêmica, e sugere-se ampliação da pesquisa para avaliação de outros aspectos, verificando a integração de Fatores ESG às estratégias das firmas. Adicionalmente, sugere-se que o estudo seja ampliado e replicado no período pós-pandemia, de modo a mapear longitudinalmente a disseminação das iniciativas analisadas em setores diretamente impactados pela pandemia, como educação, alimentação, varejo.

\section{Pesquisa realizada com fomento do Programa Pesquisa Produtividade da Estácio.}




\section{Gestãoe \\ Desenvolvimento}

e-ISSN: 2446-6875

p-ISSN: $1807-5436$

\section{REFERÊNCIAS}

ALMEIDA, H. J. L.; JÚNIOR, N. E. R.; COSTA, A. J. B. Práticas de sustentabilidade corporativa no Brasil: análise das instituições financeiras integrantes do índice de sustentabilidade empresarial. Revista Gestão e Desenvolvimento, v. 14, n. 1, p. 84-99, 2017.

ALVES, J. E. D. A covid-19 bate todos os recordes globais em novembro. Eco Debate. Disponivel em: <https://www.ecodebate.com.br/2020/11/16/a-covid-19-bate-todos-os-recordes-globais-em-novembro/>. Acesso em: 30 jul. 2020.

BERLE, A. A. Corporate Power as Powers Trustees. In: Should Corporations Serve Shareholdersor Society? The Origins of the Debate. Disponivel em: <http://corporationsandhealth.org/2011/04/06/should-corporations-serve-shareholders-or-society-the-origins-of-the-debate/>. Acesso em: 11 ago. 2020.

BOTIN, A. In: Siqueira, H. (2018). Santander apoia o lançamento dos Princípios das Nações Unidas para a Responsabilidade Bancária. Disponivel em: <https://www.segs.com.br/mais/economia/145758-santander-apoia-o-lancamento-dos-principios-das-nacoes-unidas-para-a-responsabilidade-bancaria> . Acesso em: 08 set. 2020.

BOWEN, H. Responsabilidades sociais do homem de negócios. Rio de Janeiro: Civilização Brasileira, 1957.

BRUNI, A. L. Estatística Aplicada à Gestão Empresarial. 2. ed. São Paulo: Atlas, 2008.

CAMPOS, F. M.; LEMME, C. F. Investimento socialmente responsável no mercado de capitais: análise do desempenho de índices internacionais e fundos de ações brasileiros que consideram questões ambientais e sociais. Revista Eletrônica de Administração, v. 15, n. 2, p. 2-21, 2009.

DINIZ, J. M. A.; MARQUESAN, F. F. S.; DIÓGENES, A. P.; MESQUISA, R. F. O lado obscuro das empresas ganhadoras do guia de sustentabilidade da revista exame. Revista Gestão e Desenvolvimento, v. 17, n. 3, p. 239-258, 2020.

DUPRAT, C. C. A empresa na comunidade: um passo-a-passo para estimular sua participação social. Editora Global, 2005.

ESG. Considerations for Official Institutions. 2018. Disponivel em: <http://www.schroders.com/hu/ sysglobalassets/digital/events/pdfs/oi-and-esg-thought_leadership_brochure.pdf >. Acesso em: 02 maio 2020. 


\section{Gestãoe \\ Desenvolvimento}

e-ISSN: 2446-6875

p-ISSN: $1807-5436$

FEKETE, O.; TATAY, T. Moral aspects of rental terms. Acta Scientiarum Socialium, v. 38, p. 145-151, 2013. Disponivel em: <http://www.journal.ke.hu/index.php/asc/article/view/304>. Acesso em: 10 jun. 2020.

FTFS - Força Tarefa Brasil - Finanças Sociais. Como As Instituições Financeiras Locais e Internacionais Estão se Posicionando no Tema de Investimento de Impacto. 2017. Disponível em: < http://ice.org.br/ wp-content/uploads/2018/07/Paper-Produtos-Financeiros-ICE-Itaú-Português.pdf >. Acesso em: jul. 2020.

FTFS - Força Tarefa Brasil - Finanças Sociais. 0 Papel de Bancos de Desenvolvimento no Campo das Finanças Sociais. 2014. Disponível em: <http://forcatarefafinancassociais.org.br/wp-content/uploads/2015/01/2014_10_15-Paper-FT-O-Papel-de-Bancos-de-Desenvolvimento-no-Campo-das-Financas-Sociais.pdf >. Acesso em: 15 jul. 2020.

FEM - Fórum Econômico Mundial. Novos negócios terão de levar em conta o meio ambiente. Disponível em: <https://www.msn.com/pt-br/noticias/meio-ambiente/fórum-econômico-mundial-"novos-negócios-terão-de-levar-em-conta-o-meio-ambiente"/ar-BB16PpqE?ocid=spartan-ntp-feeds>. Acesso em: 12 jul. 2020.

FRIEDMAN, M. The social responsibility of business is to increase profit. The New York Times Magazine, p. 13-33, 1970.

GENTIL, D.; FERREIRA, G. T. C. Como as Empresas Integrantes da Carteira ISE Avaliam o Retorno do Investimento Social Privado. Revista Organizações em Contexto, v. 15, n. 29, p. 97-123, 2019.

GIFE. Investimento Social Privado. Disponivel em: <https://gife.org.br/perfis-de-investidores/investimento-social-empresarial/>. Acesso em: 10 jul. 2020.

GOND, J. P.; PIANI, V. Enabling institutional investors' collective action: The role of the principles for responsible investment initiative. Business \& Society, v. 52, n. 1, p. 64-104, 2013.

IDOWU FILHO, S. O. Professionals perspectives of Corporate Social Responsibility. Sringer, New York, p. 978-3, 2009. DOI 10.1007/978-3-642-02630-0_8.

ICE. Instituto de Cidadania Empresarial. 2020. Disponivel em: <https://ice.org.br/financas-sociais/>. Acesso em: 05 nov. 2019.

LEVEN, R. Os mercados emergentes estão se recuperando da Covid-19? Disponível em: <https:// www.refinitiv.com/pt/blog/market-insights/os-mercados-emergentes-estao-se-recuperando-da-covid-19/>. Acesso em: 05 nov. 2019. 


\section{Gestãoe \\ Desenvolvimento}

e-ISSN: 2446-6875

p-ISSN: $1807-5436$

LEVITT, T. The Dangers of Social Responsibility. Harvard Business Rewiew. 1958.

MACHADO, M. R.; MACHADO, M. A. V.; CORRAR, L. J. A Relação entre Investimentos Sociais e Desempenho Financeiro. XV Congresso Brasileiro de Custos. Curitiba/PR, Brasil, 12 a 14 de novembro de 2008.

MACIEL, R. S. A.; MONTEZANO, R. M. S. Desempenho de Fundos de Investimento Socialmente Responsáveis no Brasil. Revista Economia \& Gestão, v. 16, n. 42, p. 32-60, 2016.

MILANI FILHO, M. A. F. Responsabilidade Social e Investimento Social Privado: entre o discurso e a evidenciação. Revista Contabilidade \& Finanças, v. 19, n. 47, p. 89-101, 2008.

MILLER, T.; BALLIN, L. The Sustainability Imperative: Business and Investor Outlook. Bloomberg Sustainable Business \& Finance Survey. 2018.

MOSKOWITZ, M. Choosing socially responsible stocks. Business and Society, v. 1, n. 1, p. 71-75, 1972.

NWOYE, I. S. Unep-Fi Principles for Responsible Banking and The CBN Code of Corporate Governance: Improving on the Corporate Governance Discourse in Nigeria. Disponivel em: <https://www.nwoye-law. com/knowledgedevelopment/papersandpublications>. Acesso em: 28 jul. 2020.

O GLOBO. Fórum Econômico Mundial Lista os Sete Maiores Temores dos Executivos com a Pandemia. Disponivel em: <oglobo.globo.com/economia/forum-economico-mundial-lista-os-sete-maiores-temores-dos-executivos-com-a-pandemia-24435994>. Acesso em: 03 set. 2020.

PEREIRA, D.; GIL, A. C. Percepções acerca do investimento social empresarial. Revista Pretexto, v. 10, n. 2, art. 4, p. 59-72, 2009.

PERRET, N.; JUNQUEIRA, L. Investimento social privado: o papel das fundações corporativas na gestão das políticas sociais. Reuna, v. 16, n. 2, p. 121-138, 2011.

PIAZZON, R. S. O Papel das Instituições Financeiras no Fomento aos Negócios de Impacto e no Combate às Mudanças Climáticas. In: Finanças Sustentáveis e a Responsabilidade Socioambiental das Instituições Financeiras. Belo Horizonte: Fórum.

POPE FRANCESCO. Address of Pope Francis To the Participants in The Conference Promoted by The Pontifical Council for Justice and Peace On "Impact Investing for The Poor". Clementine Hall. Monday, 16 June. 2014. Disponivel em: <http://www.vatican.va/content/francesco/en/speeches/2014/june/documents/papa-francesco_20140616_convegno-justpeace.html>. Acesso em: 05 set. 2020. 


\section{Gestãoe \\ Desenvolvimento}

e-ISSN: 2446-6875

p-ISSN: $1807-5436$

PRB. Principles for Responsible Bank, 2020. Disponivel em: <https://www.unepfi.org/banking/bankingprinciples/>. Acesso em: 15 nov. 2019.

PRI. Principles for Investors in Inclusive Finance, 2011. Disponível em: <http://www.unpri.org/files/2012. 05.02\%20>. Acesso em: 12 nov. 2019.

REUTERS. FMI Aprofunda Previsão de Recessão Global para 4,9\%, devido à Pandemia, 2020. Disponível em: <cnnbrasil.com.br/business/2020/06/24/fmi-aprofunda-previsao-de-recessa0-global-para-4-9-devido-a-pandemia>. Acesso em: 05 set. 2020.

S\&P DJI. Standard \& Poor's Dow Jones Indices. Dow Jones Emerging Markets Consumer Titans Index Consultation. Disponivel em: <https://www.spglobal.com/spdji/en/index-family/esg/>. Acesso em: 04 nov. 2020

SANTOS, D. F.; MARINHO, G. A.; SILVA, W. V.; CORSO, J. M. Análise do Valor das Ações e da Inclusão das Companhias no Índice Carbono Eficiente - ICO2 da Bovespa. Revista Gestão e Desenvolvimento, v. 10, n. 2, p. 9-18, 2013.

SULLIVAN, R.; MARTINDALE, W.; FELLER, E.; BORDON, R. Fiduciary Duty in the $21^{\text {st }}$ Century, 2015. Disponivel em: <unepfi.otg/fileadmin/documents/fiduciary_duty_21st_centure.pdf>. Acesso em: 07 jul. 2020.

ULRICH, E. Disponível em: <https://portugues.spindices.com/documents/education/practice-essentials-understanding-esg-investing-por.pdf>. Acesso em: 02 jul. 2020.

UNEPFI. United Nations Environment Programme Finance Initiative. Disponível em: <http://www.unepfi. org/investment/pri/>. Acesso em: 04 out. 2020.

WARTICK, S. L.; COCHRAN, P. L. The evolution of the corporate social performance model. Academy of Management Review, v. 10, n. 4, p. 758-769, 1985.

WEF. World Economic Forum. The Global Risks Report. 2020. Disponivel em: <http://www3.weforum. org/docs/WEF_Global_Risk_Report_2020.pdf>. Acesso em: 20 jul. 2020.

WHO. World Health Organizarion. Painel do WHO Coronavirus Disease (COVID-19). Disponivel em: <https://covid19.who.int/>. Acesso em: 04 nov. 2019.

YOSHIDA, C. Y. M.; KISHI, S.; PIAZZON, R. S.; VIANNA, M. D. B. (2017). Finanças Sustentáveis e a Responsabilidade Socioambiental das Instituições Financeiras. Belo Horizonte: Fórum. 